Gulf universities are being structurally "synchronized" with American universities, while exposure to other Arab, most notably Egyptian, universities is being considerably narrowed in scope. Some view these shifts as reflecting globalization and internationalization trends in higher education, in an increasingly competitive market. Yet, one should also consider the geopolitical corollaries. The Americanization and privatization of Gulf universities are occurring in conjunction with regional and global realignments of strategic military and economic alliances. The mechanisms underpinning this process still await solid research, not only with respect to the role academic models play in mediating foreign policies but also the impact academic models exert on regional economic and political (dis)integration.

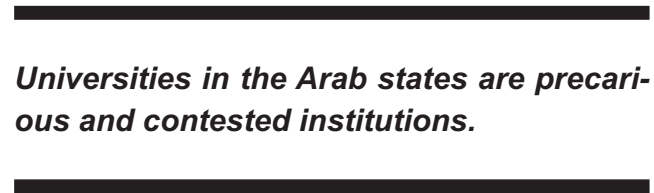

Reconceptualizing Globalization and Internationalization

Universities in the Arab states are precarious and contested institutions. Colonial legacies, state authoritarianism, civil wars, and military conflicts weaken their societal and economic impact, expectations to the contrary notwithstanding. Academic freedom, university autonomy, quality of higher education, and the enduring brain drain raise grave concerns. State administrators often prevail in decision making, at the expense of faculty and student participation, regardless of the academic model in place. In The Ontology and Status of Intellectuals in Arab Academia and Society (Aldershot: Ashgate, 2001), M'hammed Sabour shows that modes of governance and administration reproduce within universities clientelism and patrimonial relations.

The impact of wars and geopolitics on university governance, as illustrated above, points to the urgent need to refine the concepts of globalization and internationalization, taking into account the dynamic of wars and the subtleties of geopolitical struggles in any credible account of university restructuring. The economic retrenchment of the state and the corporatization of universities represent just one aspect of a story dominated by economic rationality and discourse. Military and geopolitical conflicts unleash other forces associated with globalization and internationalization, leading states to implement policies that play a hegemonic role in university reforms. States are retrenching, economically speaking, but they have not yielded the trenches. At this juncture, whither universities?

\section{Palestinian Universities Under}

\section{Siege}

\section{Fouad Moughrabi}

Fouad Moughrabi is professor of political science at the University of Tennessee, Chattanooga. He is also director of the Qattan Center for Educational Research and Development, Ramallah, Palestine. Address: Department of Political Science, University of Tennessee, Chattanooga, Chattanooga, TN 37403, USA. E-mail: fouad-moughrabi@utc.edu.

Tn a comprehensive review of the history and problems of Palestinian higher education, the late Professor Ibrahim Abu-Lughod points out that "Palestine's institutions of higher education were developed under the most trying social, political, and economic circumstances, the result of a military occupation determined to disempower Palestinian society" (Palestinian Higher Education: National Identity, Liberation, and Globalization, Duke University Press, 2000). These conditions have prevailed from the start of the June 1967 Israeli occupation until today. The story of how Palestinian education has withstood the cumulative effects of a harsh military occupation needs to be told because it illustrates both the resilience of the Palestinian people and the futility of Israel's politics of force.

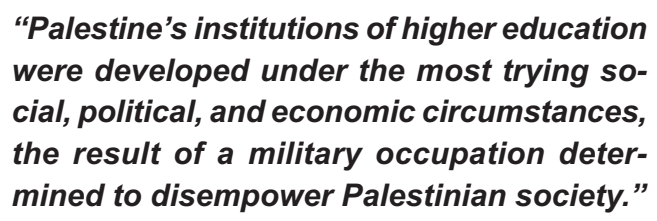

“Palestine's institutions of higher education were developed under the most trying social, political, and economic circumstances, the result of a military occupation determined to disempower Palestinian society."

Eleven Palestinian universities, 5 university colleges, and 26 community colleges operate in the West Bank and the Gaza Strip, serving a population of 3.5 million people. Nearly all the institutions were established after 1971, when a small university opened its doors in Hebron. According to the 2002 census, 3,474 teaching faculty serve 83,408 students at all Palestinian higher education institutions.

By 2003, nearly three years into the Intifada and as a result of Israel's major military assault against Palestinian society (curfews, closures, checkpoints, house demolition, forced entry, and destruction of public buildingsincluding the two ministries of education), Palestinian institutions of higher education suffered serious human (24 teachers, 194 students, and 7 employees killed and 1,245 students injured) and material losses (estimated at $\$ 4.85$ million). Overall casualty figures are in excess of 3,000 dead and nearly 20,000 injured. 
Societies can easily recover from material destruction. However, damage to human capital-in the form of death, injury, psychological impairment, malnutrition, school dropouts, and the emigration of skilled labor-can have irreversible consequences at the level of individual families. As a result of income compression, nearly 20 percent of the student body in Palestinian higher education is no longer able to pay its fees.

Access to higher education institutions by students and faculty has become very difficult as a result of long curfews and other drastic restrictions on freedom of movement. In many cases, however, university faculty began to communicate with their students via the Internet in an attempt to overcome Israeli-imposed restrictions on freedom of movement. A new phenomenon of distance learning began to emerge, leading to a student-centered kind of education. In some cases, universities tried to find alternate venues for holding classes and seminars in neighboring cities. The problem here is that not every student has access to email and many students are scattered in villages away from urban centers.

The financial crisis facing higher education presents a much more difficult challenge.

So strong is the belief in the positive value of education that most students would brave checkpoints, curfews, and life-threatening restrictions in order to arrive at their schools. At the same time, most of the faculty, despite the fact that they have not received their full salaries for months on end, would also put up with tremendous difficulties to meet their classes. Simply attending school and meeting classes become major acts of defiance, turning universities and schools into sites of resistance. In addition, families pool their limited resources to help defray the costs of education for their sons and daughters.

The financial crisis facing higher education presents a much more difficult challenge. A 2003 World Bank report ("Two Years of Intifada: Closures and Palestinian Economic Crisis") states that "Palestinian institutions face the worst financial crisis over the last thirty odd years and their continued operation without emergency assistance is in serious doubt." Some institutions will reduce offerings, increase class size, and rely on part-time or unqualified instructors. An exodus of qualified faculty was already under way even before the Intifada. The crisis has exacerbated this phenomenon as capable teachers begin to look for better-paying opportunities in the various nongovernmental organizations working in the country.
Some universities have moved in the direction of setting up new degree programs and graduate programs that have higher tuition rates. They also began relaxing admissions requirements as a way of increasing revenue. Library holdings have begun to decline and journal subscriptions are not being renewed mainly as a result of lack of funding and the unreliability of postal delivery. All of these factors eventually will lead to a precipitous decline in quality, something that Palestinians can ill afford and may take many years to remedy.

In general, the Ministry of Higher Education has tried to deal with this crisis in three ways: tuition and fees have increased sharply as a percentage of the overall budget (now at 70 percent); a student revolving-loan fund was initiated to enable needy students to obtain low-interest loans to cover tuition; a voucher system was also created, although not yet implemented, whereby universities receive public funding by cashing in student vouchers.

The Ministry of Higher Education has succeeded in the creation of an autonomous, semiofficial commission responsible for the accreditation and licensing of new programs and institutions. This commission reviews existing criteria, develops new criteria for accreditation, and produces procedures for an ongoing assessment of all programs that grant academic degrees. All this is based on a two-tier methodology of self-evaluation and external review.

Other possible developments, including streamlining, the modernizing of management systems, and the establishment of consortia are being delayed because of the crisis. These measures relate mostly to the financial crisis and are aimed not only at trying to make do in abnormal conditions but also in the long run, paving the way for future reform. It is not clear whether these measures will enable the universities to withstand the cumulative effects of a protracted war situation and an endemic financial crisis.

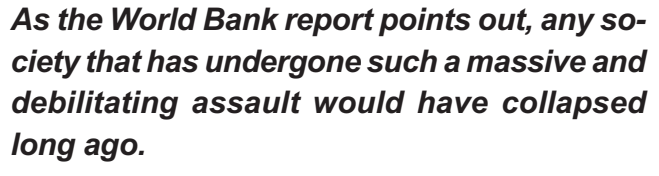
ciety that has undergone such a massive and debilitating assault would have collapsed long ago.

As the World Bank report points out, any society that has undergone such a massive and debilitating assault would have collapsed long ago. The fact is that the Palestinians have shown incredible resilience in the face of adversity. How long they can continue to suffer is not clear especially since a political resolution of the conflict with Israel still appears very far off. 